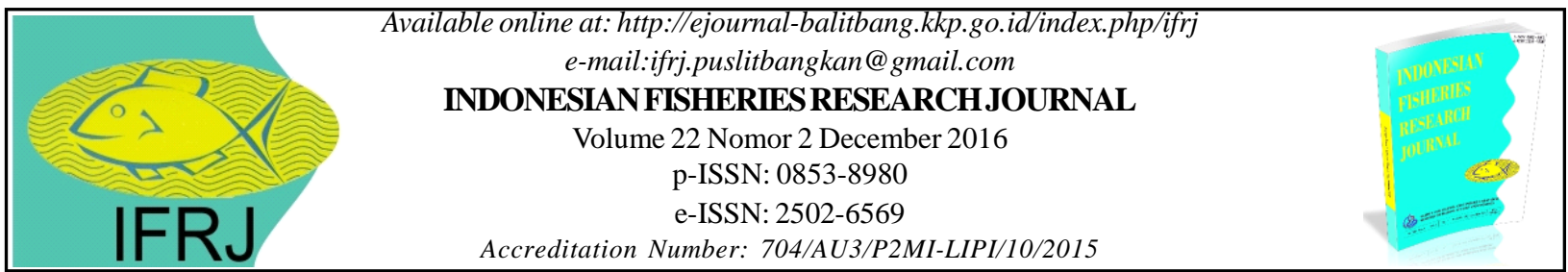

\title{
ESTIMATION OF YELLOWFIN TUNA PRODUCTION LANDED IN BENOA PORT WITH WEIGHT-WEIGHT, LENGTH-WEIGHT RELATIONSHIPS AND CONDITION FACTOR APPROACHES
}

\author{
Irwan Jatmiko*1, Hety Hartaty ${ }^{1}$ and Budi Nugraha² \\ ${ }^{1}$ Research Institute for Tuna Fisheries, Jl. Mertasari No. 140, Sidakarya, Denpasar Selatan, Denpasar, Bali - 80224. Indonesian \\ ${ }^{2}$ Research Institute for Marine Fisheries, Jl. Muara Baru Ujung, Komp Pelabuhan Perikanan Nizam Zachman, Penjaringan, \\ Jakarta Utara, Jakarta - 14440. Indonesian \\ Received; August 20-2014 Received in revised from Dec 5-2016; Accepted December 15-2016
}

\begin{abstract}
Yellowfin tuna (Thunnus albacares) is one of the important catch for the fishing industry in Indonesia. Length-weight relationship study is one of important tools to support fisheries management. However it could not be done to yellowfin tuna landed in Benoa port since they are in the form of gilled-gutted condition. The objectives of this study are to determine the relationship between gilled-gutted weight $(G W)$ and whole weight (WW), to calculate length weight relationship between fork length $(F L)$ and estimated whole weight (WW) and to assess the relative condition factor $\left(K_{n}\right)$ of yellowfin tuna in Eastern Indian Ocean. Data were collected from three landing sites i.e. Malang, East Java; Benoa, Bali and Kupang, East Nusa Tenggara from January 2013 to February 2014. Linear regression analysis applied to test the significance baseline between weight-weight relationships and log transformed length weight relationship. Relative condition factor $\left(K_{n}\right)$ used to identify fish condition among length groups and months. The results showed a significant positive linear relationships between whole weight (WW) and gilled-gutted weight $(G W)$ of $T$. albacares $(p<0.001)$. There was a significant positive linier relationships between log transformed fork length and log transformed whole weight of $T$. albacares $(\mathrm{p}<0.001)$. Relative condition factor $\left(K_{n}\right)$ showed declining pattern along with length increase and varied among months. The findings from this study provide data for management of yellowfin tuna stock and population.
\end{abstract}

Keywords: Weight-weight relationships; length-weight relationships; condition factor; yellowfin tuna; Eastern Indian Ocean

\section{INTRODUCTION}

Tuna is one of important export commodity in Indonesia with total production reaches 1.352 .802 tons from 2005 to 2012. Yellowfin tuna is the highest percentage with $72 \%$ from total big tuna group production, followed by bigeye tuna (21\%), albacore $(6 \%)$ and southern bluefin tuna (1\%) (DGCF, 2015). Yellowfin tuna (Thunnus albacares) is highly migratory species with distribution in trophic and temperate water. This species can be found in Atlantic, Hindian and Pacific Ocean (Collette \& Nauen, 1983). In Indonesia, the distribution of this species spreading from west and south Sumatera; south of Java, Bali and Nusa Tenggara; Banda and Sulawesi Sea; and west of Papuan waters (Uktolseja et al., 1991).

Length-weight relationship study is one of an important tool to support fisheries management. This information can estimate the average weight from known fish length which can then be used to estimate the biomass of fish population (Froese, 2006). Furthermore, length-weight relationships and condition factor studies were applied to support stock assessment of population (Ricker, 1979) and also valuable to understand the life history including reproduction aspect and general health of the species (Pauly, 1993).

One of the important tuna landing site in Indonesia is located in Benoaport, Bali. Different with albacore that landed in whole condition in this port, three other species of tuna were processed onboard (removing gill and stomach content) and landed in gilled-gutted condition. This process performed to maintain the quality of the fish for export destination. However, this procedure affects the loss of fish weight due to gill and gutted removal. The objectives of this study are 
to determine the weight-weight relationship between gilled-gutted weight (GW) and whole weight (WW), to calculate length weight relationship between fork length (FL) and whole weight (WW) and to assess the relative condition factor $\left(K_{n}\right)$ of yellowfin tuna in Eastern Indian Ocean. The finding of this study be able to become data base for the estimation of yellowfin tuna production. Moreover, the results from this study can be used to determine the quota for yellowfin tuna in the Regional Fisheries Management Organization (RFMO).

\section{MATERIALS AND METHODS}

\section{Data Collection}

Yellowfin tuna data were collected from three landing sites i.e. Malang, East Java; Benoa, Bali and Kupang, East Nusa Tenggara (Figure 1). For weightweight relationships study, the fish samples gained from August 2013 to February 2014 in Malang, East Java and Kupang, East Nusa Tenggara. The fork length
$(F L)$ of fish was measured $( \pm 1 \mathrm{~cm})$, weighing whole weight (WW) and gilled-gutted weight $( \pm 0.01 \mathrm{~kg})$ with a digital balance. The yellowfin tuna from these sites were caught by handline fishing. For length-weight relationships and condition factor study, other fish samples were measured monthly by enumerator from January to December 2013 in Benoa, Bali. The fork length $(F L)$ of fish was measured $( \pm 1 \mathrm{~cm})$, weighing gilled-gutted weight $( \pm 1 \mathrm{~kg})$ with a regular balance. The yellowfin tuna from this site was caught by longline fishing.

The first survey conducted from August 2013 to February 2014 collected 79 samples with fork length ranged $26-68 \mathrm{~cm}$, whole weight (WW) ranged 0.32$6.40 \mathrm{~kg}$ and gilled-gutted weight (GW) ranged 0.27$5.80 \mathrm{~kg}$. The second survey covered a period of 12 consecutive months from January to December 2013. A total of 7,254 measured samples of $T$. albacares were examined with fork lengths (FL) ranging from 77 to $180 \mathrm{~cm}$ and gilled-gutted weight $(\mathrm{GW})$ ranged 8$103 \mathrm{~kg}$ (Table 1).

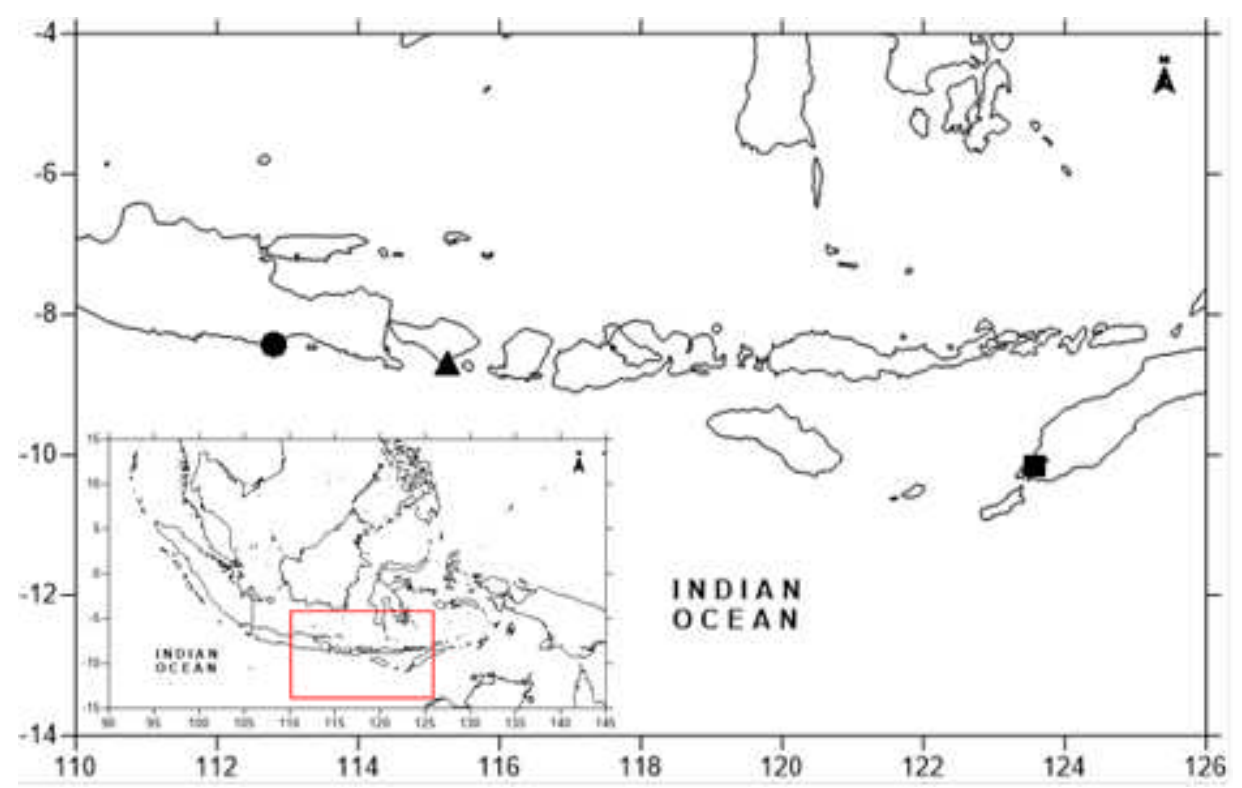

Figure 1. Sampling site in Malang, East Java (circular), Benoa, Bali (triangle) and Kupang, East Nusa Tenggara (square).

Table 1. The summary of descriptive statistics of $T$. albacares samples.

\begin{tabular}{|c|c|c|c|c|c|c|c|}
\hline \multirow{2}{*}{ Survey } & \multirow{2}{*}{$N$} & \multicolumn{2}{|c|}{ Fork length $(\mathrm{cm})$} & \multicolumn{2}{|c|}{ Whole weight $(\mathrm{kg})$} & \multicolumn{2}{|c|}{ Gilled-gutted weight $(\mathrm{kg})$} \\
\hline & & Range & $M e a n \pm S E$ & Range & Mean $\pm S E$ & Range & $M e a n \pm S E$ \\
\hline I & 79 & $26-68$ & $41.73 \pm 1.05$ & $0.32-6.40$ & $1.51 \pm 0.11$ & $0.27-5.80$ & $1.33 \pm 0.10$ \\
\hline II & 7254 & $77-180$ & $132.53 \pm 0.20$ & - & - & $8-103$ & $43.21 \pm 0.19$ \\
\hline
\end{tabular}




\section{Data Analysis}

Relationships between whole weight (WW) and gilled-gutted weight (GW) was analyzed using linear regression model $Y=a+b X$, where $a$ is intercept and $b$ is slope.Linear regression analysis performed to determine the amount of deviation in $Y$ variable explained by $X$ variable. Test for linear regression was conducted to examine the significance between two variables (Barnett, 2003). This relationship was used to convert from gilled-gutted weight data into estimated whole weight data to generate length-weight relationships.

The relationships between the length and estimated whole weight of a fish calculated using equation, $W=a L^{b}$. Where $W$ is body weight $(\mathrm{kg}), L$ is fork length $(\mathrm{cm}), a$ is a coefficient related to body form and $b$ is an exponent indicating fish growth (Ricker, 1979).

Log transformed length and log transformed weight were plotted in order to examine the significance between these two variables. Values of the exponent $b$ provide information on fish growth. When $b=3$, increase in weight is isometric. When the value of $b$ is other than 3 , weight increase is allometric, (positive allometric if $b>3$, negative allometric if $b<3$ ). The null hypothesis of the isometric growth $\left(H_{0}: b=3\right)$ was tested using $t$-test (Morey et al., 2003).
To detect seasonal variations in the condition of the fish, relative condition factors $\left(K_{n}\right)$ were calculated from monthly samples. The conditional factors can be calculated by comparing the mean weight of fish in a sample with the predicted weight of fish from a generalized length-weight relationship using equation (King, 2007):

Where:

$$
K n=\frac{W_{m}}{W_{p}}
$$

$K_{n}=$ relative condition factor

$W_{m}=$ monthly of mean weight

$W_{p}^{m}=$ general predicted weight of fish from the same mean length

\section{RESULTS AND DISCUSSION \\ Results}

\section{Whole Weight (WW) and Gilled-gutted Weight (GW) Relationship}

There was a significant positive linear relationships between whole weight (WW) and gilled-gutted weight (GW) of $T$. albacares $\left(F_{1.77}=80,383.60, p<0.001, R^{2}\right.$ $=0.999$ ). As gilled-gutted weight increases, the whole weight of $T$. albacares increases. Gilled-gutted weight explained $99 \%$ variation in the whole weight of $T$. albacares with equation WW $=1.1167 \mathrm{GW}+0.0266$ (Figure 2).

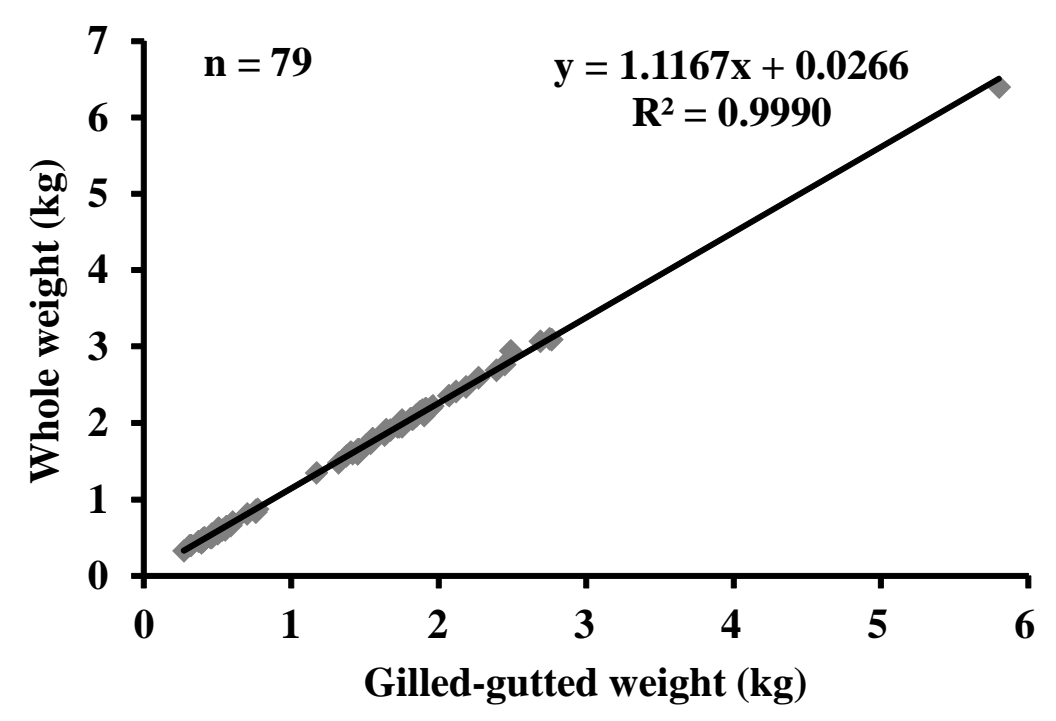

Figure 2. Weight-weight relationships between gilled-gutted weight (GW) and whole weight (WW) of $T$. albacares in Eastern Indian Ocean. 


\section{Length and Estimated Whole Weight (WW) Relationship}

Monthly descriptive statistics and estimated parameters of length-weight relationships for $T$. albacares were shown in Table 1. Growth pattern of $T$. albacares showed that positive allometric growth occurred in January, March, April, October and December. Whereas the isometric growth appeared in February, May, June, July, August, September and November. Overall, the growth pattern of $T$. albacares in Eastern Indian Ocean is isometric (Table 2).

Length-weight analysis showed the equation $\mathrm{W}=$ $0.00002 L^{3.0294}$ with coefficient determination $\left(R^{2}\right)$ 0.9635 . Fork length explained $96 \%$ variation in the weight of $T$. albacares (Figure 3).

Table 2. Monthly growth pattern of yellowfin tuna caught in Indian Ocean southern of Java, Bali and Nusa Tenggara

\begin{tabular}{|c|c|c|c|c|c|c|c|c|c|}
\hline \multirow{2}{*}{ Month } & \multirow{2}{*}{$N$} & \multicolumn{2}{|c|}{ Fork length $(\mathrm{cm})$} & \multicolumn{2}{|c|}{ Whole weight $(\mathrm{kg})$} & \multicolumn{3}{|c|}{ Parameters } & \multirow{2}{*}{ Growth pattern } \\
\hline & & Range & Mean $\pm S E$ & Range & Mean $\pm S E$ & $a$ & $b$ & $R^{2}$ & \\
\hline Jan & 672 & $79-176$ & $127.29 \pm 0.74$ & $10-106$ & $44.88 \pm 0.76$ & 0.00001 & 3.0892 & 0.9774 & Positive all \\
\hline Feb & 336 & $77-165$ & $124.06 \pm 0.94$ & $10-90$ & $39.78 \pm 0.94$ & 0.00002 & 3.0295 & 0.9605 & Isometric \\
\hline Mar & 292 & $85-165$ & $125.85 \pm 0.96$ & $12-98$ & $41.41 \pm 1.04$ & 0.00001 & 3.1056 & 0.9642 & Positive allometric \\
\hline Apr & 462 & $87-171$ & $126.77 \pm 0.73$ & $15-103$ & $42.33 \pm 0.79$ & 0.00001 & 3.1221 & 0.9545 & Positive allo \\
\hline May & 980 & 89-174 & $136.21 \pm 0.50$ & $12-95$ & $51.57 \pm 0.55$ & 0.00002 & 3.0459 & 0.9696 & Isometric \\
\hline Jun & 958 & 91-171 & $134.95 \pm 0.52$ & $17-93$ & $50.11 \pm 0.57$ & 0.00002 & 3.0261 & 0.9614 & Isometric \\
\hline Jul & 1337 & $81-172$ & $136.13 \pm 0.46$ & $11-90$ & $50.95 \pm 0.47$ & 0.00002 & 2.9555 & 0.9469 & Ison \\
\hline Aug & 257 & $94-162$ & $133.42 \pm 0.89$ & $13-86$ & $46.27 \pm 0.89$ & 0.00002 & 2.9565 & 0.9576 & Isometric \\
\hline Sep & 328 & $81-165$ & $128.67 \pm 0.73$ & $10-88$ & $43.98 \pm 0.74$ & 0.00002 & 2.9985 & 0.9389 & Isometric \\
\hline Oct & 369 & $80-180$ & $129.98 \pm 1.05$ & $9-115$ & $48.14 \pm 1.08$ & 0.000009 & 3.1779 & 0.9664 & Positive all \\
\hline Nov & 600 & $80-169$ & $133.63 \pm 0.82$ & $10-102$ & $50.41 \pm 0.81$ & 0.00002 & 3.0217 & 0.9793 & Isometric \\
\hline Dec & 663 & $85-173$ & $134.88 \pm 0.62$ & $11-105$ & $51.38 \pm 0.66$ & 0.00001 & 3.0700 & 0.9693 & Positive allometric \\
\hline All & 7254 & $77-180$ & $132.53 \pm 0.20$ & $9-115$ & $48.30 \pm 0.21$ & 0.00002 & 3.0294 & 0.9635 & Isometric \\
\hline
\end{tabular}

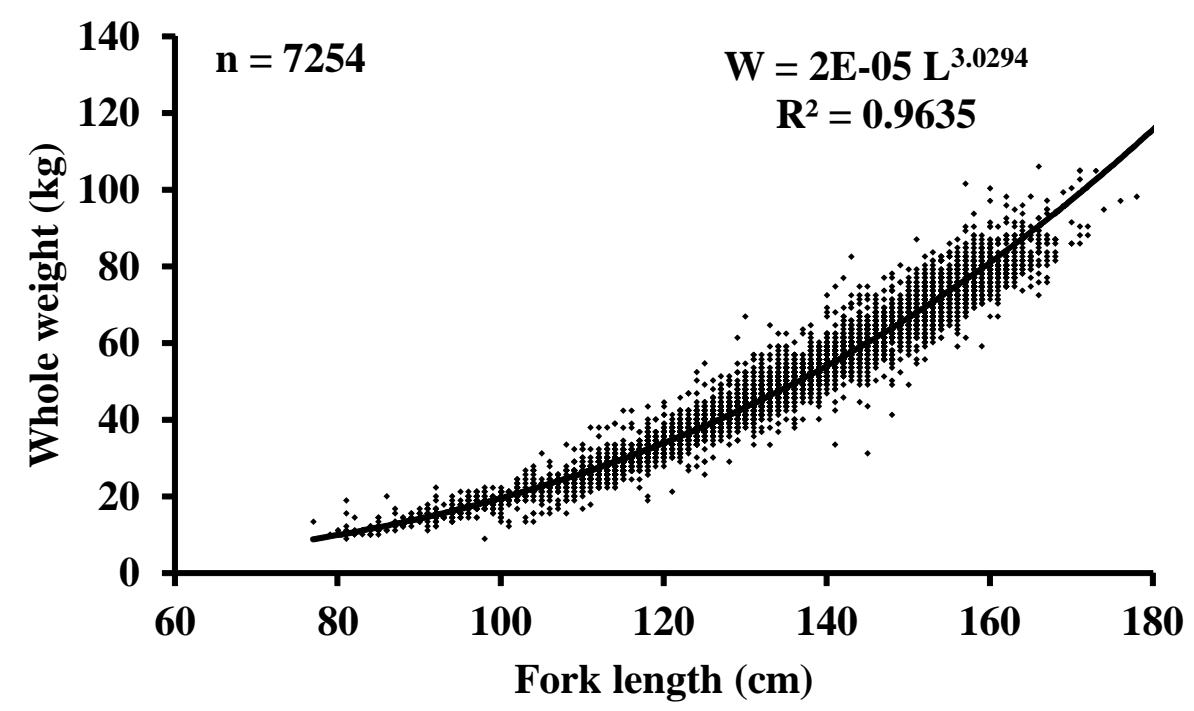

Figure 3. Length-weight relationships between fork length (FL) and whole weight (WW) of $T$. albacares in Eastern Indian Ocean. Whole weight data were estimated from weight-weight relationship. 


\section{Relative Condition Factor $\left(K_{n}\right)$}

The relative condition factor $\left(K_{n}\right)$ has been calculated for each $5 \mathrm{~cm}$ length groups. Generally, the relative condition factor $\left(K_{n}\right)$ decreased along with the increasing of fork length. The highest value with 1.04 occurred at length group $80 \mathrm{~cm}$ then decreased significantly up to 0.83 at length group $110 \mathrm{~cm}$. There has been slightly increased at length group $115 \mathrm{~cm}$ and tend to steady until length group $160 \mathrm{~cm}$ then decline drastically to 0.75 at length group $180 \mathrm{~cm}$ (Figure 4).

Monthly relative condition factor $\left(K_{n}\right)$ of $T$. albacares showed fluctuated during the year. The highest relative condition factor $\left(K_{n}\right)$ occurred in March with 0.89 and the lowest appeared in August with 0.82 (Figure 5).

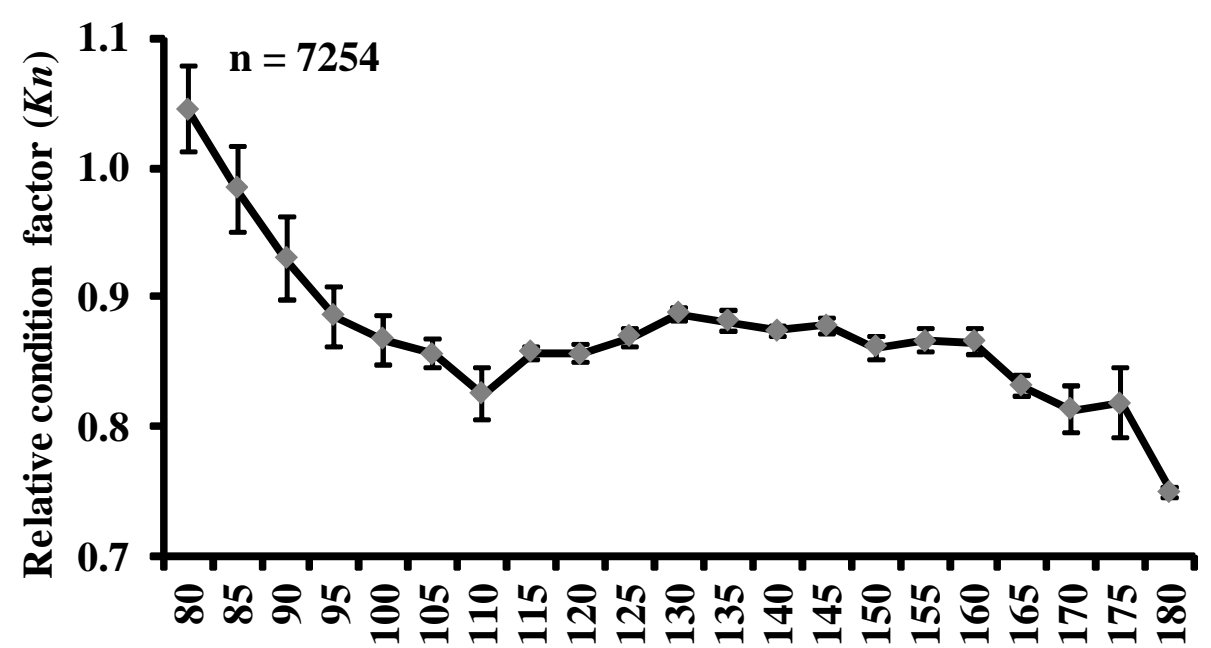

Fork length (cm)

Figure 4. Variation of relative condition factors (mean \pm SE) of $T$. albacares in Eastern Indian Ocean. Values on fork length are the upper limit of $5 \mathrm{~cm}$ length groups.

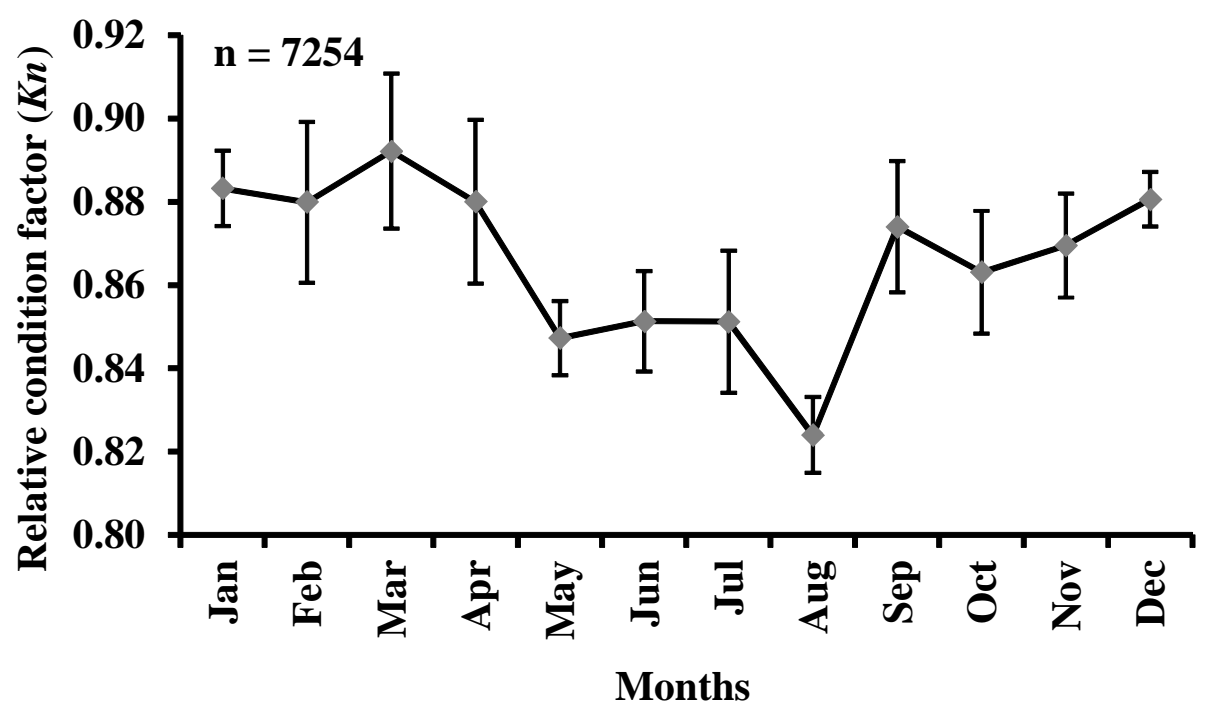

Figure 5. Monthly relative condition factors (mean \pm SE) of $T$. albacares in Eastern Indian Ocean. 


\section{Discussion}

Weight-weight relationships and length-weight relationships studies are important for fisheries management, for example in calculating yield and biomass (King, 2007). However, processing fish on board had consequences in the loss weight of the fish. This study showed that additional weight of $T$. albacares landed in Benoa port ranged from $1.2 \mathrm{~kg}$ at length class $80 \mathrm{~cm}$ to $10.2 \mathrm{~kg}$ at length class 180 $\mathrm{cm}$. The additional weight increased along with the increase of length. The increasing length of fish leads the greater on the weight of the fish.

Length-weight relationship showed that a value (intercept) is less influential than $b$ value (slope) to the equation because its value is very small (Table 3 ). The a value in this study is 0.00002 , relatively similar to other studies except in Indian Ocean, Sri
Lanka waters with a value is 0.033 (Perera et al., 2013). The $b$ value in this study is 3.029 higher than other studies except in Pacific Ocean with $b$ value is 3.244 (Zhu et al., 2010). After $t$-test analysis the result showed that this value is not significantly different $(b=3)$, ensuing that growth pattern of $T$. albacares is isometric. It means that growth occurred at the same rate for length and weight of the fish so that its shape is consistent throughout development or in the same dimension as the cube of length (Pauly, 1984). This growth pattern is different with other studies in Atlantic and Indian Ocean where the growth pattern is negative allometric and in Pacific Ocean where the growth pattern is positive allometric (Zhu et al., 2010). The variability of growth pattern of fish can be depend on the food availability, season and environmental conditions (Froese, 2006; Effendie, 2002) and the swimming activity of the fish (Muchlisin et al., 2010).

Table 3. Estimated parameters of length-weight relationships for T. albacares from various studies.

\begin{tabular}{|c|c|c|c|c|c|}
\hline Location & $a$ & $b$ & $R^{2}$ & Growth pattern & Reference \\
\hline $\begin{array}{l}\text { Pacific Ocean, } \\
\text { Taiwan }\end{array}$ & 0.00004 & 2.854 & - & - & $\begin{array}{l}\text { Wang et al. } \\
2002\end{array}$ \\
\hline $\begin{array}{l}\text { Pacific Ocean, } \\
\text { Hawaii }\end{array}$ & 0.00003 & 2.889 & 0.975 & - & $\begin{array}{l}\text { Uchiyama \& } \\
\text { Kazama, } 2003\end{array}$ \\
\hline Atlantic Ocean & 0.00002 & 2.969 & 0.941 & $\begin{array}{l}\text { Negative } \\
\text { allometric }\end{array}$ & $\begin{array}{l}\text { Zhu et al. } \\
2010\end{array}$ \\
\hline Indian Ocean & 0.00002 & 2.985 & 0.969 & $\begin{array}{l}\text { Negative } \\
\text { allometric }\end{array}$ & $\begin{array}{l}\text { Zhu et al. } \\
2010\end{array}$ \\
\hline Pacific Ocean & 0.000004 & 3.244 & 0.945 & $\begin{array}{l}\text { Positive } \\
\text { allometric }\end{array}$ & $\begin{array}{l}\text { Zhu et al. } \\
2010\end{array}$ \\
\hline $\begin{array}{l}\text { Indian Ocean, } \\
\text { Sri Lanka }\end{array}$ & 0.033 & 2.848 & 0.918 & - & $\begin{array}{l}\text { Perera et al. } \\
2013\end{array}$ \\
\hline $\begin{array}{l}\text { Indian Ocean, } \\
\text { Indonesia }\end{array}$ & 0.00002 & 3.029 & 0.964 & Isometric & Present study \\
\hline
\end{tabular}

Condition factor $\left(K_{n}\right)$ was used to identify the condition of the fish. Study on salmonid fish showed that the higher $K_{n}$ value showed fish in good condition. On the contrary, the lower $K_{n}$ value showed poor condition (Barnham \& Baxter, 1998). The similar results occured in this study. The relative condition factor $\left(K_{n}\right)$ of $T$. albacares showed high value for small fish and decreased along with the development of fish length. There was steep declining of relative condition factor $\left(K_{n}\right)$ when fish reach $106-110 \mathrm{~cm}$ to 0.83 . This decreased probably related with the reproduction strategies of yellowfin tuna which reach their length at $50 \%$ maturity $\left(L_{50}\right)$ at $102 \mathrm{~cm}$ (Zudaire et al., 2013), $105 \mathrm{~cm}$ (Itano, 2000), $105 \mathrm{~cm}$ for male and $110 \mathrm{~cm}$ for female (Nootmorn et al., 2005) and 110-115 (Hassani \& Stequert, 1991).

Monthly relative condition factor $\left(K_{n}\right)$ showed high value from September to April with the highest value occurred in March with 0.89. On the other hand, it showed low value from May to August with the lowest value happened in August with 0.82. It means that the index of well-being of the fish from September to April was better than the condition of the fish from May to August. The variability of relative condition factor $\left(K_{\mathrm{n}}\right)$ among months allegedly due to seasonal variations which may vary with food availability and dietary habit (King, 2007; Saha et al., 2009). 
Moreover, monthly condition factor also influenced by environmental condition (Froese, 2006; Effendie, 2002). Indian Ocean waters has distinctive characteristics that its environmental condition had influence from Indian Ocean Dipole-zonal Mode/IODM (Li et al., 2003), El Nino Southern Oscillation/ENSO (Reason et al., 2000) and monsoon (Yang et al., 2007). Monsoon can be categorized into four segments, which are west monsoon (Dec-Feb), transitional season I (Mar-May), east monsoon (JunAug) and transitional season II (Sep-Nov). Monthly condition factor showed that well-being index of yellowfin tuna is better in west monsoon and transitional II. It was allegedly as this season occurred healthy of water fertility that have a positive impact on the availability of abundant food resources (Realino et al., 2010).

\section{CONCLUSION}

The strong positive linear relationship between whole weight and gilled-gutted weight resulted from this study indicated that the total weight of yellowfin tuna that landed in Benoa Port can be estimated from gilled-gutted weight (processed weight). Therefore, this finding can be used to determine the quota for yellowfin tuna in Regional Fisheries Management Organizations (RFMO's). The growth in weight and length of yellowfin tuna is proportional to each other with its relative condition factor tend to decrease along with the increasing of length.

\section{ACKNOWLEDGEMENT}

This study is funded by research project at Research Institute for Tuna Fisheries. The authors wish to thank all enumerators for their contribution in data collection.

\section{REFERENCES}

Barnett, V. (2003). Environmental Statistics: Methods and Applications (p. 320). Wiley, London, UK.

Barnham, C., \& Baxter, A. (1998). Condition Factor, K, for Salmonid Fish. Fisheries Notes (p. 3). Department of Primary Industries, Victoria, Australia.

Collete, H.B., \& Nauen, C.E. (1983). FAO Species Catalogue. Vol. 2.Scombrids of the world. An Annonated and illustrated catalogue of tunas, mackerels, bonitos, and related species known to date, FAO Fisheries Synopsis No. 125, Vol. 2(p. 137). Rome, Italy: FAO Press.
Directorate General Capture Fisheries (DGCF). (2015). Statistik Perikanan Tangkap Indonesia 2014 (p. 190). Directorate General Capture Fisheries, Ministry of Marine Affairs and Fisheries, Jakarta, Indonesia.

Effendie, M.I. (2002). Biologi Perikanan (Fisheries Biology) (p. 155). Yogyakarta, Indonesia: Yayasan Pustaka Nusatama.

Froese, R. (2006). Cube law, condition factor and weight-length relationships: history, meta-analysis and recommendations. Journal of Applied Ichthyology, 22,241-253.

Hassani, S., \& Stequert, B. (1991). Sexual maturity, spawning and fecundity of the yellowfin tuna (Thunnus albacares) of the western Indian Ocean. In FAO Indo-Pacific Tuna Development and Management Programme. Collective volume of working documents presented at the Expert Consultation on Stock Assessment of Tunas in the Indian Ocean (pp. 91-107). Bangkok, Thailand.

Itano, D. (2000). The reproductive biology of yellowfin tuna (Thunnus albacares) in Hawaiian waters and the western tropical Pacific Ocean: Project summary (p. 75). SOEST 00-01, JIMAR Contribution 00-328.

King, M. (2007). Fisheries Biology, Assessment and Management, Second Edition (p. 381). Oxford, England: Blackwell Publising Ltd.

Li, T., B. Wang, C.P., \& Zhang, Y.S. (2003). A theory for the Indian Ocean Dipole-Zonal Mode. Journal of the Atmospheric Sciences. 60, 2119-2135.

Morey, G., Moranta, J., Massuti, E., Grau, A., Linde,M., Riera, F., \& Morales-Nin, B. (2003). Weight-length relationships of littoral to lower slope fishes from the Western Mediterranean. Fisheries Research. 62, 89-96.

Muchlisin, Z. A., Musman, M., \& Azizah, M.N.S. (2010). Length-weight relationships and condition factors of two threatened fishes, Rasbora tawarensis and Poropuntius tawarensis, endemic to Lake Laut Tawar Aceh Province, Indonesia. Journal of Applied Ichthyology. 26(6), 949-953.

Nootmorn, P., Yakoh, A., \& Kawises, K. (2005). Reproductive biology of yellowfin tuna in the eastern Indian Ocean (p. 8). Working Party on Tropical Tunas. IOTC-2005-WPTT-14. Phuket, Thailand. 
Pauly, D. (1993). Fishbyte Section Editorial Naga (pp. 16-22). Manila Phillipines: The ICLARM Quarterly.

Pauly, D. (1984). Fish population dynamics in tropical waters: a manual for use with programmable calculators (p. 325). Manila, Phillipines: ICLARM contribution No. 143.

Perera, H. A.C.C., Haputhanthri, S.S.K., \& Bandaranayake, K.H.K. (2013). A review on oceanic tuna fishery in Sri Lanka and estimation of the length-weight relationships for yellowfin tuna and bigeye tuna (p. 8). IOTC-2013-WPTT15-16.

Realino, B., Wibawa, T.A., Zahrudin, D.A., \& Napitu, A.M. (2010). Pola spasial dan temporal kesuburan perairan permukaan laut di Indonesia (p. 10). Bali, Indonesia: Balai Riset dan Observasi Kelautan.

Reason, C.J.C., Allan, R.J., Lindesay, J.A., \& Ansell, T.J. (2000). ENSO and climatic signals across the Indian Ocean basin in the global context: part I, interannual composite patterns. International Journal of Climatology. 20, 1285-1327.

Ricker, W.E. (1979).Growth rate and models. In Hoar, W.S., D.J. Randall \& J.R. Brett (Ed.) Fish Physiology. Vol. III. Bioenergetics and Growth (pp. 195-248). Academic Press.

Saha, S. N., Vijayanand, P., \& Rajagopal, S. (2009). Length-weight relationship and relative condition factor in Thenus orientalis (Lund, 1793) along East Coast of India. Curr. Res. J. Biol. Sci. 1(2), 11-14.

Uchiyama, J.H., \& Kazama, T.K. (2003). Updated Weight-on-Length Relationships for Pelagic Fishes Caught in the Central North Pacific Ocean and Bottom fishes from the Northwestern Hawaiian
Islands (p. 46). Pacific Islands Fisheries Science Center, National Oceanic and Atmospheric Administration, Hawaii, USA.

Uktolseja J.C.B., Gafa, B., \& Bahar, S. (1991). Potensi dan penyebaran sumber daya ikan tuna dan cakalang. In Martosubroto P., N.Naamin \& B.B.A. Malik (Ed.) Potensi dan Penyebaran Sumber daya Ikan Laut di Perairan Indonesia (pp. 29-43). Jakarta: Direktorat Jenderal Perikanan: Pusat Penelitian dan Pengembangan Oseanologi.

Wang, S.B., Chang, F.C., Wang, S.H., \& Kuo, C.L. (2002). Some biological parameters of bigeye and yellowfin tunas distributed in surrounding waters of Taiwan (p. 13). Hawaii, USA: Standing Committee on Tuna and Billfish (SCTB).

Yang, J.L., Liu, Q.Y., Xie, S.P., Liu, Z.Y., \& Wu, L.X. (2007). Impact of the Indian Ocean SST basin mode on the Asian summer monsoon. Geophysical Research Letters, 44, L02708, doi:10.1029/2006GL028571.

Zhu, G.P., Xu, L.X., Zhou, Y.Q., Song, L.M. \& Dai, X.J. (2010). Length-weight relationships for bigeye tuna (Thunnus obesus), yellowfin tuna (Thunnus albacares) and albacore (Thunnus alalunga) (Perciformes: Scombrinae) in the Atlantic, Indian and Eastern Pacific Oceans. Collect. Vol. Sci. Pap. ICCAT. 65(2), 717-724.

Zudaire, I., Murua, H., Grande, M., \& Bodin, N. (2013). Reproductive potential of yellowfin tuna (Thunnus albacares) in the western Indian Ocean.Fishery Bulletin. 111, 252-264. 